\title{
UM TEMA NEGLIGENCIADO.
}

\author{
JOSE ROBERTO DO AMARAL LAPA \\ da Universidade Estadual de Campinas (SP).
}

Surgindo no século XIX, como um dos instrumentos de maior alcance do Capitalismo Industrial, a estrada de ferro, como a literatura histórica tem suficientemente demonstrado, ao impulsionar a indústria do carvão, a siderurgia e a engenharia pesada, contribuiu de maneira decisiva para consolidar o arranco e a maturidade daquele Sistema, que dela tanto se beneficiou.

Entretanto, a ferrovia não desempenhou apenas esse papel, e também não o fez somente na frente de expansão do núcleo central - do Sistema, ritmando mesmo o seu crescimento, mas e também em sua periferia, onde contudo assumiu diferentes funções, de ordem econômica, política, estratégica e cultural, o que não só se mantinha sintonizado com o interesse da alta burguesia européia, detentora dos meios de produção, como também atendia, dentro de um complexo de relações econômicas e sociais, aos que manipulavam a organização da produção no interior da periferia.

A partir daí, o Sistema acabou não tendo outra alternativa, se não a de consentir tacitamente em sua faixa periférica que esse poderoso instrumento acabasse também por implicar num certo processo de crescimento das áreas dependentes, identificando-se nelas como o símbolo do progresso.

Foi com essa última imagem, nutrida pelos modelos europeu e norte-americano, que geralmente se comprometeu a historiografia brasileira, muito embora reconhecesse, por outro lado, ter a ferrovia representado sempre um setor privilegiado para as inversões inglesas na América, e portanto para a preeminência de uma nação colonizadora sobre a nossa economia e sociedade.

Essa visão crítica geralmente compreendeu e se conteve ao nível do complexo representado pela introdução de capitais, know-how, mão-de-obra qualificada e garra empresarial. Escapou-lhe no entan- 
to a performance das ferrovias na circulação e consumo das manufaturas que alimentavam, vestiam e abrigavam a população brasileira do século XIX, marcando seu estilo urbano de vida, numa desembaraçada competição ao artesanato, à manufatura e à incipiente indústria local.

Essa e outras questǒes continuam ainda reclamando estudos em nossa história econômica, a fim de que se possa avaliar, com maior precisão, o que realmente representaram as ferrovias no processo de modernização e desenvolvimento da sociedade brasileira.

Por sua vez, como tema de estudo, as ferrovias não têm recebido um tratamento científico à altura de sua importância. Poucas e insuficientes monografias, que vão dos estudos técnicos às reportagens, ficando ao nível do folclore ou muitas vezes do sensacionalismo que envolveu a construção de certas ferrovias, compõem a bibliografia que se pode utilizar nesse sentido. Raramente verifica-se a preocupação em compreender a ferrovia inserta na emergência capitalista na qual se perfila o país a partir do século XIX.

Relegada por uma estratégia viária que privilegiou a rede rodoviária do país nos últimos trinta anos, ao ponto de provocar um desequilíbrio de difícil e lenta recuperação, a ferrovia sofreu contínua obsolência e deterioração, não tendo mais condições de responder ao desenvolvimento do país em termos de comunicação e do transporte de passageiros e de cargas. Entretanto, esse quadro, ao* que tudo indica, tende a modificar-se forçado pela crise do petróleo em que se debate o Brasil.

Sensibilizada de um lado pelo ocaso em que mergulharam as ferrovias e possivelmente agora também pelas perspectivas que se desenham nesse sentido, isto é, de voltar a ser um transporte ideal de massas e cargas, a médias e longas distâncias, a produção intelectual acadêmica vem recuperando as estradas de ferro como objeto de estudo, dentro e fora do país, dispensando-lhes um tratamento científico, que está contribuindo de maneira rápida para alterar o quadro bibliográfico que criticamos no quarto parágrafo desta resenha (1).

(1). - Na Universidade de São Paulo vem de ser defendidas duas teses de Mestrado em Economia, versando o tema das ferrovias: Flávio Azevedo Marques de Saes, As ferrovias de São Paulo: Paulista, Mogiana e Sorocabana (1870-1940), São Paulo 1974 e Júlio Colombi, $O$ declínio das ferrovias $e o$ transporte de passageiros de médio e longo percurso, São Paulo 1975. Na Universidade Federal Fluminense o Prof. Almir Chaiban El-Karech estuda $A$ Companhia Estrada de Ferro D. Pedro II: uma tentativa capitalista no Brasil Imperial. Nos Estados Unidos o Prof. Robert Havard Matoon escreveu um trabalho sobre The Cia! Paulista de estradas de ferro $1868 / 1900$ a local railway interprise in São Paulo, Brasil, Universidade de Yale 1971. 
Revaloriza-se assim a temática ferroviária para entendimento do processo de desenvolvimento brasileiro, em termos sobretudo da lavoura cafeeira e da industrialização.

Em obra recente, o Prof. Odilon Nogueira de Matos oferece a pormenorizada história da evolução da rede ferroviária em São Paulo, inventariando a legislação pertinente e desintrincando a teia em que se teceu essa rede, com as costumeiras omissões, resistências, retificações, erros e falhas, responsáveis pela sua desarticulação, cuja crônica hitórica foi agora pacientemente recolhida pelo autor (2).

As direções para onde se irradia o leque de ferrovias, envolvendo e envolvido pelos programas de desbravamento e povoamento, alcance de mercados, veiculação de notícias e modernização de costumes foram também explicados pelo autor, cujo interesse pelo tema, como se sabe, já fora anteriormente demonstrado através de trabalhos menores, em mais de uma oportunidade.

Sobre o café particularmente, ao registrar sua historiografia no Brasil (págs. 36 e segs.), embora a bibliografia básica tradicional seja lembrada, as contribuições mais modernas - como abordagem e esquema analítico - que dimensionam o tema em suas implicações sociais e políticas também, não são referidos. E o caso, por exemplo,

- de alguns trabalhos de Octavio Ianni, Fernando Henrique Cardoso, Warren Dean, Celso Furtado, Nelson Werneck Sodré e outros muitos. Também não foram utilizados autores como Richard Morse e Richard Graham, que ofereceram contribuição para o estudo do binômio café-ferrovias.

Preocupando-se mais com a demorada reconstituição de uma realidade histórica - a do flutuante crescimento ferroviário - que na verdade apresenta-se complexo e mal informado para o pesquisador, o autor nos permite avaliar o esforço do seu trabalho.

Entretanto, se suaviza o texto, evitando discretamente a frequiência das descrições técnicas e da arrumação de dados estatísticos, que acabariam entediando o leitor, por outro lado é levado a não poucas concessões que não trazem ciência para essas suas páginas.

A sistemática organização de um acervo de informações que forçarão por certo o estudioso a recorrer a este livro, é a sua maior contribuição ao tema, ao que se acrescentam ainda as sugestões para pesquisas mais setorizadas, a partir das revelações que nos traz.

(2). - Odilon Nogueira de Matos, Café e Ferrocias, Editora Alfa-Omega, São Paulo, 1974. 